\title{
Omental metastasis with malignant ascites: an unusual manifestation of prostatic adenocarcinoma
}

\author{
Sanjeev Madaan, FRCS; ${ }^{*}$ Victor Palit, FRCS; ${ }^{*}$ Patricia Gudgeon, MRCPath; ${ }^{\dagger}$ Chandra Shekhar Biyani, FRCS
}

\begin{abstract}
Omental metastasis with malignant ascites from prostatic adenocarcinoma is rare. This case report is about a patient who presented with a 24-hour history of a swollen right leg. Clinical examination revealed a hard prostate and blood biochemistry demonstrated an elevated prostate specific antigen level. A Doppler ultrasound scan excluded deep venous thrombosis, but a CT scan of the abdomen revealed marked para-aortic lymphadenopathy and prostate gland biopsy confirmed prostatic adenocarcinoma. The patient was treated with goserelin. Three years later, he presented with ascites and an omental mass. Histology of the omental mass showed metastasis from the prostatic adenocarcinoma. He was treated with second-line hormonal therapy but died after 4 months. We discuss the clinical progression, with a review of the literature.
\end{abstract}

CUAJ 2007;1(3):288-90

\section{Introduction}

Every year in the United Kingdom nearly 32000 cases of prostate cancer are diagnosed. Prostate cancer causes more than 10000 deaths in the United Kingdom each year. ${ }^{1}$ Prostate cancer has a tendency to metastasize to bones and lymph nodes. It rarely gives rise to intraabdominal secondary cancer. ${ }^{2}$ We report a case of omental metastasis and malignant ascites secondary to the prostate cancer, which is a rare manifestation of this disease. There is only one previous report of a case of prostate cancer that metastasized to the omentum and was accompanied by gross ascites. ${ }^{3}$

\section{Case Report}

A 75-year-old man presented acutely to the accident and emergency department with a 24-hour history of a swollen right leg. His past medical history was unremarkable. The right leg was markedly swollen, with pitting edema up to the thigh. On digital rectal examination, the patient was found to have a malignant feeling prostate. Routine blood tests were unremarkable. Prostate specific antigen (PSA) was elevated at $92.9 \mathrm{ng} / \mathrm{mL}$. A Doppler ultrasound of his leg showed no evidence of a deep venous thrombosis. An abdominal ultrasound revealed extensive para-aortic lymphadenopathy and right hydronephrosis. CT scan confirmed extensive retroperitoneal lymphadenopathy involving mainly right para-caval and inter-aortocaval nodes, markedly compressing the inferior vena cava and causing right hydronephrosis. A right percutaneous nephrostomy was performed followed by the insertion of an antegrade JJ stent to manage right renal obstruction because an attempt at retrograde stenting was unsuccessful. A possible diagnosis of prostate cancer was made, which was subsequently confirmed by transrectal ultrasound guided prostate biopsy that revealed prostatic adenocarcinoma with a Gleason sum score of 9 . The patient was started on hormone therapy with goserelin.

Two months after starting treatment, the patient's leg edema had resolved. A repeat CT scan at that time confirmed that the right hydronephrosis had resolved. His PSA had dropped to $5.4 \mathrm{ng} / \mathrm{mL}$. The JJ stent was removed. A further CT scan 12 months later revealed almost complete resolution of abdominal and pelvic adenopathy. His PSA had dropped to $0.2 \mathrm{ng} / \mathrm{mL}$ at 12-month follow-up.

Three years after the patient's initial presentation, he was readmitted with a 10-day history of abdominal bloating but had no other symptoms. On examination, he had gross ascites. His PSA had risen to $10.3 \mathrm{ng} / \mathrm{mL}$. Abdominal ultrasound confirmed a large volume of ascites with no focal liver lesions. There was a $7 \times 9 \mathrm{~cm}$ irregular mass in the upper abdomen. Abdominal paracentesis was performed, with a large volume of hemorrhagic fluid aspirated. Cytological examination of the fluid revealed areas of atypical epithelial cells, which were suspicious of neoplasia. Reactive mesothelial cells were also seen. CT scan confirmed ascites with multiple nodular mass lesions within the omentum and mesentery, the largest in the omentum measuring $9 \times 9 \mathrm{~cm}$ (Fig. 1). A CT-guided biopsy of the omental mass was performed and histology of the omentum biopsy showed fibro-fatty omental tissue infiltrated by metastatic cribriform carcinoma consistent with secondary prostate cancer (Fig. 2). The patient was started on diethylstilboestrol (1 mg/d) and ASA (75 mg/d) as a 
second-line therapy. However, he developed recurrent ascites and required multiple admissions for therapeutic paracentesis and packed cell transfusions for anemia. The patient died 4 months after his first presentation with ascites.

\section{Discussion}

Malignant effusions may occur in the pleural or peritoneal cavities, but they are very uncommon manifestations of prostate carcinoma. ${ }^{2}$ Although these effusions may constitute the initial presenting feature of prostate cancer, they may be the only sign of recurrence of prostatic disease. ${ }^{4-6}$ Ten cases of malignant ascites secondary to prostatic carcinoma have been reported in the literature (Table 1). Table 1 shows that patients have a poor survival rate after presentation with ascites. Two of these had chylous ascites, while 1 was a case of hemorrhagic ascites. The mechanism of ascites may include peritoneal seedlings or lymphatic obstruction. Chylous ascites secondary to prostatic carcinoma has also been reported. ${ }^{7}$ It has been suggested that the measurement of PSA may be a valuable adjunctive study for the diagnosis of malignant effusions in prostate cancer. ${ }^{8}$

Malignant effusions secondary to prostatic adenocarcinoma are mostly seen in relation to poorly differentiated prostatic adenocarcinoma and generally show poor response to hormonal manipulation, although Kehinde and colleagues reported a 76-year-old man who presented with palpable omental metastasis and gross ascites due to prostate cancer who responded well to surgical castration. ${ }^{3}$ Unfortunately, in our patient the disease was much more aggressive.

In conclusion, omental metastasis and malignant ascites are potential complications of prostatic adenocarcinoma. This report serves to highlight that prostate cancer can present in a myriad of ways, including ascites. It should always be considered when evaluating elderly male patients presenting with ascites or pleural effusion and a history of prostatic adenocarcinoma.

From the *Department of Urology, Pinderfields General Hospital, Wakefield, West Yorkshire, UK, and the †Department of Pathology, Dewsbury District Hospital, Dewsbury, West Yorkshire, UK

This article has been peer reviewed.

Competing interests: None declared.

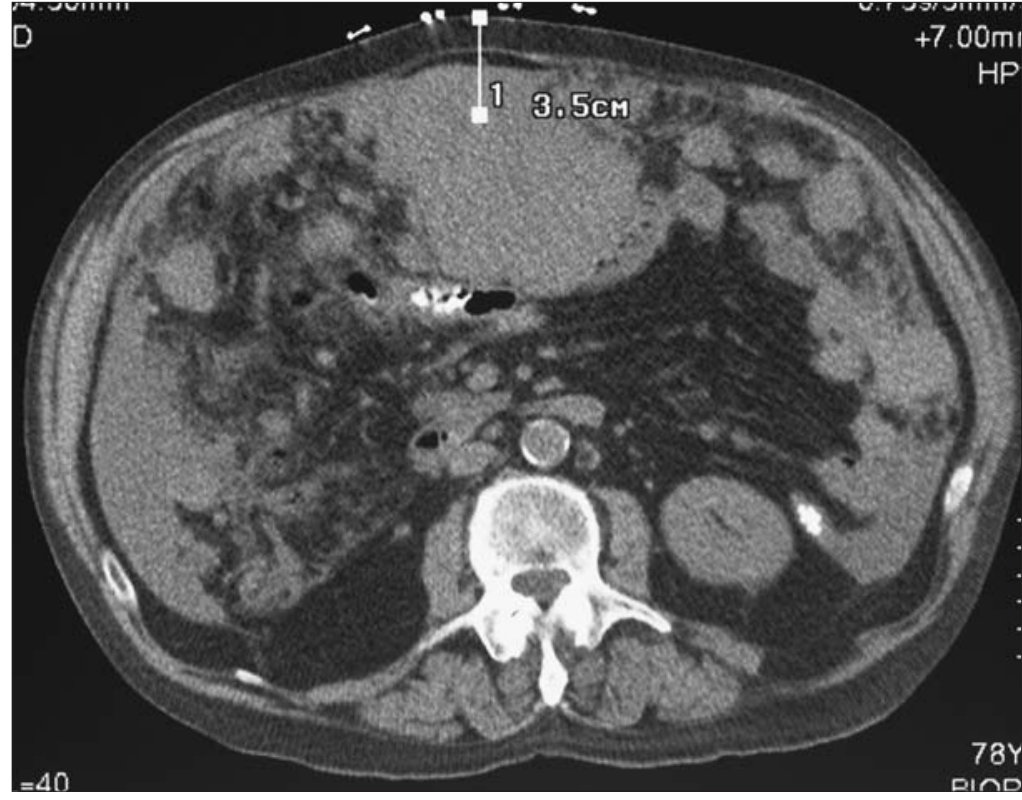

Fig. 1. CT scan showing ascites with a large nodular mass lesion within the omentum.

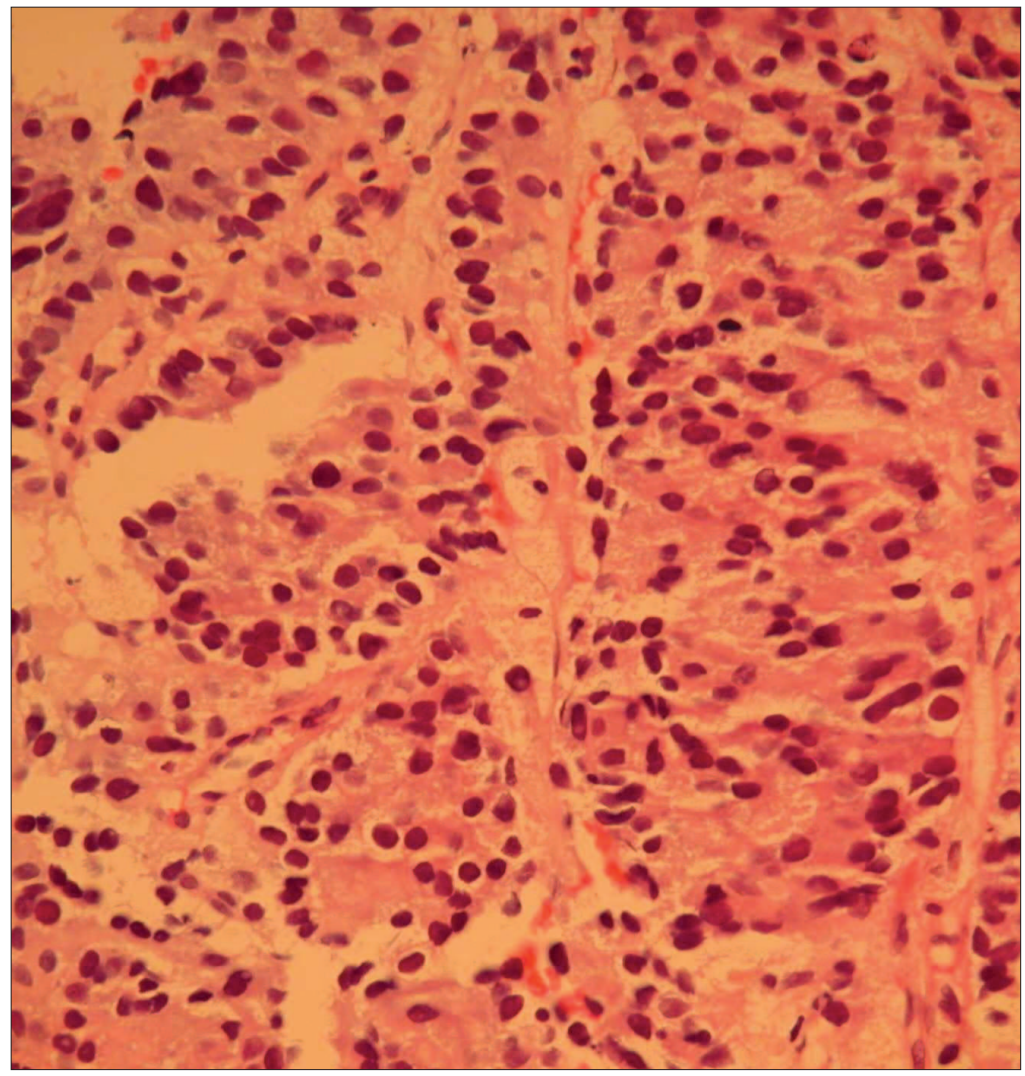

Fig. 2. Histology of the omental biopsy showing omental tissue infiltrated by metastatic cribriform carcinoma consistent with prostatic primary cancer (haematoxylin-eosin stain, original magnification $200 \times$ ). 
Table 1: Reported cases in the literature of malignant ascites in prostate cancer

\begin{tabular}{|c|c|c|c|c|c|c|c|}
\hline Reference & $\begin{array}{l}\text { Patient } \\
\text { age, yr }\end{array}$ & Type of ascites & $\begin{array}{c}\text { Primary prostate } \\
\text { histology }\end{array}$ & $\begin{array}{c}\text { Time gap } \\
\text { between first } \\
\text { diagnosis and } \\
\text { ascites, yr }\end{array}$ & $\begin{array}{c}\text { Other } \\
\text { metastases }\end{array}$ & Treatment & $\begin{array}{c}\text { Survival after } \\
\text { presentation, } \\
\text { mo }\end{array}$ \\
\hline \multirow[t]{2}{*}{ Rapoport et al ${ }^{4}$} & 76 & NA & $\begin{array}{l}\text { Well differentiated, } \\
\text { mucin secreting } \\
\text { adenocarcinoma }\end{array}$ & 16 & $\begin{array}{l}\text { Pleural } \\
\text { effusion, } \\
\text { lymph } \\
\text { nodes }\end{array}$ & $\begin{array}{l}\text { Intraperitoneal } \\
5-F U \text { and } \\
\text { thiotepa }\end{array}$ & 3 \\
\hline & 45 & Greenish fluid & NA & 1 & $\begin{array}{l}\text { Pleural } \\
\text { effusion }\end{array}$ & $\begin{array}{l}\text { Surgical } \\
\text { castration }\end{array}$ & Few mo \\
\hline Catton $^{5}$ & 63 & NA & $\begin{array}{l}\text { Poorly } \\
\text { differentiated, } \\
\text { signet-ring variant }\end{array}$ & $\begin{array}{c}\text { Initial } \\
\text { presentation }\end{array}$ & $\begin{array}{l}\text { Lymph } \\
\text { nodes }\end{array}$ & $\begin{array}{l}\text { Surgical } \\
\text { castration }\end{array}$ & 13 \\
\hline$A \min ^{7}$ & 83 & Chylous ascites & $\begin{array}{l}\text { Adenocarcinoma } \\
\text { (unknown grade) }\end{array}$ & 5 & $\begin{array}{l}\text { Lymph } \\
\text { nodes }\end{array}$ & Hormonal & 4 \\
\hline Appalaneni ${ }^{8}$ & 60 & Straw coloured & $\begin{array}{l}\text { Gleason } 9 \\
\text { adenocarcinoma }\end{array}$ & 3 & Bone & $\begin{array}{l}\text { Palliative } \\
\text { chemotherapy }\end{array}$ & 1.5 \\
\hline Megalli ${ }^{9}$ & 58 & Straw coloured & $\begin{array}{l}\text { Adenocarcinoma } \\
\text { (unknown grade) }\end{array}$ & $\begin{array}{c}\text { Initial } \\
\text { presentation }\end{array}$ & None & $\begin{array}{l}\text { Radiotherapy, } \\
\text { hormonal } \\
\text { (DES) }\end{array}$ & $\begin{array}{l}\text { Ascites } \\
\text { resolved; alive } \\
\text { at } 6 \text { mo }\end{array}$ \\
\hline Beigel $^{10}$ & 29 & Chylous ascites & $\begin{array}{l}\text { Adenocarcinoma } \\
\text { (unknown grade) }\end{array}$ & $\begin{array}{c}\text { Initial } \\
\text { presentation }\end{array}$ & Bone & Refused & 1 \\
\hline Tsai $^{11}$ & 68 & Haemorrhagic & $\begin{array}{l}\text { Gleason } 9 \\
\text { adenocarcinoma }\end{array}$ & 1 & Rectal wall & $\begin{array}{l}\text { Hormones + } \\
\text { interferons }\end{array}$ & 4 \\
\hline Present case & 75 & Haemorrhagic & $\begin{array}{l}\text { Gleason } 9 \\
\text { adenocarcinoma }\end{array}$ & 3 & Omentum & $\begin{array}{l}\text { Hormonal } \\
\text { (DES) }\end{array}$ & 4 \\
\hline
\end{tabular}

\section{References}

1. Cancer Research UK. UK prostate cancer statistics. Available: http://info.cancerresearchuk.org/cancerstats/types/prostate/ (accessed 2007 July 25)

2. Kirby RS, Christmas TJ, Brawer MK, eds. Clinical diagnosis. In: Prostate cancer. London: Mosby; 2001. p. 49-59.

3. Kehinde E0, Abdeen SM, Al-Hunayan A, et al. Prostate cancer metastatic to the omentum. Scand I Urol Nephrol 2002;36:225-7.

4. Rapoport AH, Omenn GS. Dermatomyositis and malignant effusions: rare manifestations of carcinoma of the prostate. J Urol 1968;100:183-7.

5. Catton PA, Hartwick RW, Srigley JR. Prostate cancer presenting with malignant ascites: signet-ring cell variant of prostatic adenocarcinoma. Urology 1992;39:495-7.

6. Saif MW, Figg WD, HewittS, et al. Malignant ascites as only manifestation of metastatic prostate cancer. Prostate Cancer Prostatic Dis 1999;2:290-3.
7. Amin R. Chylous ascites from prostatic adenocarcinoma. Urology 2002;59:773

8. Appalaneni V, Yellinedi S, Baumann MA. Diagnosis of malignant ascites in prostate cancer by measurement of prostate specific antigen. Am J Med Sci 2004;327:262-3.

9. Megalli MR, Gursel E0, Veenema RJ. Ascites as an unusual presentation of carcinoma of the prostate. J Urol 1973;110:232-4.

10. Beigel Y, Zelikovski A, Shimoni S, et al. Chylous ascites as a presenting sign of prostatic adenocarcinoma. Lymphology 1990;23:183-6.

11. Tsai JY, Ling M, Chang VT, et al. Hemorrhagic ascites: an unusual manifestation of prostate carcinoma. Am J Med 2001;111:245-6.

Correspondence: Mr. Chandra Shekhar Biyani, Department of Urology, Orchard House, Pinderfields General Hospital, Aberford Road, Wakefield WF1 4DG, West Yorkshire, UK; fax +44 1924 212921; shekharbiyani@hotmail.com 